\title{
ANDRAGOGIC APPROACH AS A BASIS FOR THE FORMATION OF PROFESSIONAL MOBILITY OF FUTURE TEACHERS OF PHYSICAL EDUCATION
}

\section{Denysenko Nataliia $^{1}$}

DOI: http://dx.doi.org/10.30525/978-9934-571-27-5_18

Abstract. The problem of professional flexibility of the prospective PE teachers is a new phenomenon in the national pedagogical science. The given materials are peculiar because the author explores the andragogic approach from the historical-practical perspective.

In this monograph the phenomena of professional flexibility formation during the process of Physical Education prompted the author to make scientific correlations between the historical background of flexibility and the modern international practice. Perhaps for the first time the attention of sporting community was diverted to the system of professional flexibility formation among the prospective PE teachers with regards to the needs of the national school.

The periodisation, suggested by the author is as follows: Sophistic period (Ancient history), Middle Ages; Pansophistic period (New Age XVII century); The period or Reformation K. D. Uschynsky (second half XIX c. beginning of XX c.); Explicit period (second half of XVIII c. - XIX c.); Constructively-flexible period in adult education (end of XX c. - begging of XXI c.); Mentorship period (70-s to present XX c.); The period of Competency (in active use in 60-s of XX c. and is still used nowadays); Cluster period (starting in 2015 and until nowadays).

As the result of author's historical-pedagogical analysis, the scientific content was enriched with a considerable number of scattered scientific views regarding the examined phenomenon in the Physical Education. Those views are of arguable nature and that is why they almost fall out of the limits of the contemporary process of professional flexibility formation among the prospective PE teachers in the HEE environment.

\footnotetext{
${ }^{1}$ Candidate of the Pedagogical Sciences, Honoured Teacher of Ukraine, Lecturer in Theory and Methodology of Physical Education, Academy of Recreational Technologies and Law, Ukraine
} 


\section{Andragogic approach as a basis for the formation of professional mobility...}

\section{Introduction}

The transition of the modern society into an utterly different condition requires other changes in educational characteristics as well. The scientists describe it as 'mobile information' society, which is characterised by awareness about trends in the economic market. Such awareness is of fluctuating nature itself, as it has an ability to constantly transform into new forms. That is why the last century saw a change in norms of social developments, as well as rising popularity of new concepts in teaching training. Notably the training system of prospective PE (Physical Education) teachers, that has been providing methodological stability for many years, is now becoming less important in a mobile information society. In our mind, in order to resolve this problem, we need a truly innovative breakthrough in educational systems' development strategies, in management of such systems, and in theoretical foundations about organisation of a flexible learning process.

It is, thus, natural that there is a need to combine the efforts of human sciences practitioners in order to develop an integrated theory of skills formation among prospective PE teachers, which stays up-to-date and can be viewed as:

- a solution to the problematic situation emerging from insufficient personal development, which is described by famous scientists as an actively creative, unrestricted, conscious, independent social activity of a person, their own individual development, and formation of own lifestyle through trial and error $[16,11,12,13]$;

- an adaptability to new professions emerging in the labour market;

- a 'self-restoration' during the times of crisis;

- a solution to a contradiction between the necessity to provide flexible PE learning and the impossibility to do that using traditional methods (and others).

Thus, it is necessary to make a comparative analysis of different methodologies and their potential effectiveness in training of PE teachers.

We pay your attention to the fact that in teaching terminology, the term 'methodology' is one of the those that can be read in a number §of different, sometimes contradictory, ways. That is why there is no uniform meaning of this term. Through the thorough analysis of the methodological classifications available we managed to distinguish the scientific views of E. Yudin. He highlights the 'methodology of pedagogy' and considers it to be multilayered, dividing it into four levels: 


\section{Denysenko Nataliia}

1) historically-philosophical methodology;

2) general scientific methodology;

3) competitive scientific methodology;

4) disciplinary methodology (or the professional one) [19, p. 31].

Thus, the variety of methodological approaches is undeniable. Thus, let us explore the historically-philosophical methodology regarding the formation of professional flexibility of the prospective PE teachers. Because the history is the scientific foundation that preserves valuable views of educational reformers, which were verified over time. History prompts us to explore new ways and forms of reaching certain scientific aims.

One of the most successful method in this respect is the andragogical approach. In the research paper the preference is given to the andragogical approach because it can simulate the formation process of the "new flexible $\mathrm{PE}$ teacher' to the greater extent in the conditions of Higher Educational Establishment.

The term 'andragogy', created analogically to the term 'pedagogy' (from the Greek anor, Andros - meaning a 'gwown-up man' and ago - 'to lead'), was first used in 1833 by the German teacher O. Kapp (in his book 'Platon's Erziehungslehre, als Pädagogik für die Einzelnen und als Staatspädagogik'). The term was used to describe the special area of pedagogym which explores the difficulties in teaching in adult education.

As Professor O.V. Sychomlynska (Doctor of the Pedagogical Sciences) states: '.. all teachers directly practicing in an educational sphere and engaging in a social- pedagogical movement wanted to create 'a new individual', an individual of new generation, that would align with all the requirements of socio-economic challenges...' [16, p.6]. And, as the scientist believes, this aim was 'the great integrational beginning in many teachers' thoughts, which linked the ideas about a new individual with the educational developments, thoughts about its content, forms and methods of teaching, as well as forms of organisation and types of educational establishments' [16, p.6].

I. H. Herasymova seems to express a similar idea and thinks that ' $\ldots$ one of the characteristics of implementation of andragogical approach in the learning process at the Higher Educational Establishment is the necessity to transfer a student into the 'new status', namely from the position of 'I am taught' to 'I learn') [6, p.258].

Considering the above, L. Piletska also discusses the theory of a 'new teacher's' formation. At the same time, the scientist expresses concerns 


\section{Andragogic approach as a basis for the formation of professional mobility...}

that '... the transition to marketplace conditions of development, crises of global, as well as local scale, has become the reason of the teacher's of given specialty uncertain position in the labour market'. She adds that the modern professional educated to the degree level 'has very low probability of being provided with the work place, which would satisfy their aspirations and needs' [13, p. 280]. Considering the scientist's thesis, it is worth paying attention to the ways to solve this problem, that have to provide a professional with an ability to change the direction of their professional activity, master new related professions, and if needed - to change the direction of professional activity for the professional and personal fulfillment and for staying competitive in the labour market' [13, p. 280].

These observations help to establish that the problem of educational flexibility of 'adults' stays in the range of scientific inquiries of representatives from the psychological and pedagogical sciences, which correlates with the tendencies of modern Ukrainian society. Clearly, the research into problems of professional flexibility of prospective teachers is just at the beginning. However, despite the small number of approved candidates' dissertations there is some valuable research done for the purposes of obtaining the Doctor's degree. Among this research are the works of A. Artushenko, L. Amirova, A. Vaschenko, L. Vovk, O. Diomina, N. Koshemiakina, Y. Mysychenko, L. Merkylova, R. Prima, L. Piletska, N. Panasenko.

With such an aim in mind, we consider it appropriate to analyse the history of the given problem and establish the necessary connections with the system of formation of the professional flexibility of prospective PE teachers. As V. A. Kovalchuk highlights, the history is 'the necessary scientific foundation, which stimulates a search of new ways and forms of achieving the given goals' $[8$, p. 24]. It is rather obvious that the reference to the pedagogical legacy of the past, an in-depth exploration of pedagogical approaches, where the problems of adult education are highlighted, leads to its better understanding and sage in the process of reformation of the higher educational system in the sphere of physical education.

It is worth mentioning that as a result of historical-pedagogical analysis we tried to explore the periodisation of flexibility genesis in adult education. The outcome of this analysis was the segregation of the certain periods, shown in the table 1. 


\section{The periods of creation and developments in problems of the formation of a professional flexibility of the prospective PE teachers in a historical context}

\begin{tabular}{|c|c|}
\hline $\begin{array}{l}\text { The periods of } \\
\text { the formation of a } \\
\text { professional flexibility } \\
\text { of the prospective } \\
\text { PE teachers }\end{array}$ & $\begin{array}{l}\text { The outline of system theories' development, } \\
\text { the founders }\end{array}$ \\
\hline \multirow[t]{2}{*}{$\begin{array}{l}\text { Sophistic period } \\
\text { (Ancient history), } \\
\text { Middle Ages }\end{array}$} & $\begin{array}{l}\rightarrow \text { the formation of a theoretical system of nurturing of } \\
\text { prospective philosopher-kings in a 'perfect polis' with } \\
\text { expanding educational age limits to } 45 \text { years (Plato) }\end{array}$ \\
\hline & $\begin{array}{l}\rightarrow \text { the formation of new educational system model by } \\
\text { traveling (flexible) teachers - sophists (the founders of } \\
\text { sophism - Gorgias Protagoras) }\end{array}$ \\
\hline $\begin{array}{l}\text { Pan-sophistic period } \\
\text { (New Age } \\
\text { XVII century) }\end{array}$ & $\begin{array}{l}\rightarrow \text { the establishment of new science 'Pan-sophistry', that } \\
\text { implied ideas of flexibility in learning during the lifetime } \\
\rightarrow \text { the formation of new complex science about a teacher - } \\
\text { didaskology, aimed at improvements of professional training } \\
\text { of a teacher } \\
\text { (Ya. A. Komenskyy) }\end{array}$ \\
\hline $\begin{array}{l}\text { The period or } \\
\text { Reformation } \\
\text { K.D.Uschynskyy } \\
\text { (second half XIX c. - } \\
\text { beginning of XX c.) }\end{array}$ & $\begin{array}{l}\rightarrow \text { the formation of new cohort of famous scientists and } \\
\text { teachers, what have expressed a variety of views on } \\
\text { education, including the development of professional } \\
\text { flexibility (ideas of physical education in a pedagogical } \\
\text { legacy of K.D.Uschynskyy(1824-1870) serve as the } \\
\text { illustration to this period)) }\end{array}$ \\
\hline $\begin{array}{l}\text { Explicit period } \\
\text { (second half of } \\
\text { XVIII c. - XIX c.) }\end{array}$ & $\begin{array}{l}\rightarrow \text { a creation of new specific forms of adult education } \\
\text { (teaching club) and intensive developments of already } \\
\text { existing ones (higher public schools, evening, } \\
\text { weekend, educational associations, public universities } \\
\text { etc.), formation of basis for distant learning ( courses for } \\
\text { correspondents) } \\
\rightarrow \text { a destruction of 'unassisted professional swimming' } \\
\text { theory, that required the establishment of new educational } \\
\text { changes aimed at teachers' professional flexibility } \\
\text { development. } \\
\text { (Eugen Rosenstock, Hainrik Hanselmann and others) }\end{array}$ \\
\hline $\begin{array}{l}\text { Constructively } \\
\text { flexible period in } \\
\text { adult education (end } \\
\text { of XX c. - begging of } \\
\text { XXI c.) }\end{array}$ & $\begin{array}{l}\text { is characterised by the different forms of the andragogy } \\
\text { theory spreading around the world } \\
\text { (a good example for this period would be the opening of the } \\
\text { International Andragogy Institute in Venezuela) }\end{array}$ \\
\hline
\end{tabular}


Ending of Table 1

\begin{tabular}{|l|l|}
\hline $\begin{array}{l}\text { Mentorship period } \\
\text { (70-s to present) }\end{array}$ & $\begin{array}{l}\rightarrow \text { can notice interesting links between the formation of } \\
\text { professional flexibility skills and the role of a mentor } \\
\text { (researchers P. A. Early, D. Weindling confirm that the } \\
\text { American teacher M. Nowles uses the term 'andragogic } \\
\text { mentor' for the first time) }\end{array}$ \\
\hline $\begin{array}{l}\text { The period of } \\
\text { Competency } \\
\text { of XXctive use in 60-s and is still } \\
\text { used nowadays) }\end{array}$ & $\begin{array}{l}\rightarrow \text { ways of updating the educational sense and teaching } \\
\text { methods in accordance with the contemporary needs and } \\
\text { integration to international educational environment are } \\
\text { established. } \\
\rightarrow \text { re-orientation of educational programmes to competen- } \\
\text { cy-based approach and the creation of effective mechanisms } \\
\text { for their implementation } \\
\rightarrow \text { Definition and Selection of Competencies. Theoretical } \\
\text { and Conceptual Foundations' ('DeSeCo') programme was } \\
\text { established, that has tried to systemise and generalise the } \\
\text { experience from other countries } \\
\text { (one of the most prominent international experts in this filed } \\
\text { was Franz Whinert) }\end{array}$ \\
\hline $\begin{array}{l}\text { Cluster period } \\
\text { (starting in 2015 and } \\
\text { until nowadays) }\end{array}$ & $\begin{array}{l}\rightarrow \text { 15 January 2015 the scientific centre NHEE (National } \\
\text { Higher Educational Establishment) 'University of } \\
\text { Educational Management' of the National Academy of the } \\
\text { Pedagogical Sciences of Ukraine (NAPS) established the } \\
\text { 'Virtual Laboratory 'Scientific educating cluster UMO'. } \\
\text { However, until this day the legislative basis for the } \\
\text { Ukrainian cluster politics does not exist, as there are no laws } \\
\text { regarding this mode of development and this, in its turn, } \\
\text { does not promote the development of educational clusters } \\
\text { (NAPS of Ukraine) }\end{array}$ \\
\hline
\end{tabular}

Thus, let us characterise and explore the rationale behind the period segregation. We are deeply convinced that the 'lifelong learning' leads to the formations of a flexible personality, including that of the PE teacher.

\section{Sophistic period}

We deem it to be worthwhile to separate this historical context of the period in adult education. The research of Aristotle, Seneca, Confucius is taken by some scholars as the original sources of exploration into questions regarding the education of a personality. The historical exploration, conducted by L.M. Kapchenko, signifies that 'the andragogy was practiced by Pythagoras, Socrates, Plato, Jesus Christ, religious leaders and followers, philosophers, political figures, writers, scientists of different periods 


\section{Denysenko Nataliia}

and from different parts of the world. Ancient Greek and Jewish teachers were using the terminology, that emerged even before the andragogy, and included the elements of the said science, expressing its main meanings and definitions' [7, p. 7].

T.O. Lazarevych seems to hold the same opinion, saying that 'ideas of Socrates, Plato, Aristotle mirror the ideas about the lifelong learning and about the peculiarities and manners of receiving knowledge at different stages of life' [9, p.14].The author finds similar questions in the Ancient Rome as well, in works form the Renaissance age. One interesting author's discovery from the archive is that '.. during the Middle Ages, when no one was conducting any research into the adult education, it nevertheless existed in different forms almost in every European city'. Those were migrating students that '... were learning the main crafts under masters' supervision', 'such type of leaning was lasting more than one year, and also in masters' studios there were even certain rules and regulations regarding the living conditions, education, and regarding the stay of a student 'in training'. Those rules were written down in studio policies in most of the middle-aged European cities [9, p. 15].

The research by N. Demchenko adds to the theory of the lifelong learning. The researcher provides us with the convincing examples of how '... Plato in IV BC was talking about educating the future philosopher-kings in the 'ideal polis' and was advocating for the widening of the educational limits to 45 years. He thought that such a 'long road' only can lead to wisdom' [3, p. 40]. Taking the lifelong learning as the basis of the education, he wrote in 'Protagoras': '... Education and mentoring start in the early years of childhood and continue during the lifetime' [3, p. 83].

We can find the basis of this concept of adult education in the views of Y. Levchenko, who conducted the research of the archived historical materials and found the andragogical and flexibility roots in times that date back to the VIII-V centuries BC. The researcher claims that 'the Greek citystates were characterised by the cultural overturn, followed by freethinking, critical reconsideration of the established traditions, standards of thought and behaviour' $[10, \mathrm{p} .131]$. The creative freedom, achieving success in life, active developments in person's inner world were becoming the life norm, social values and even sense of person's activity. Under such circumstances the group of migrating (flexible) teachers-sophists was formed. They established the reform of the traditional educational system and led to 


\section{Andragogic approach as a basis for the formation of professional mobility...}

the development of the theoretical basis of the innovative pedagogical models (the founders of sophism - Gorgias and Protagoras; famous sophists Hippias of Elis, Prodicus of Ceos, Antiphon, Thrasymachus) [10, p. 131]. In the context of our research, an interesting idea of researchers is that the travelling teachers-sophists using the statement that ' a man is the measure of all things', justified their own ideal of a ' capable and powerful man' $[10$, p. 131]. That is why their work as flexible teachers-sophists was mostly coming to the formation of an individual, focuses exclusively on political activity, on achieving a personal success. Taking into consideration that sophists were teaching students in exchange for a certain monetary compensation, they needed to use the methods that would guarantee them success [10, p. 131].

Thus, in ancient times certain things were established, such as the andragogical foundations of the adult education; flexibility in education; the collaboration between teachers and students; skills that they must possess; the necessity of an individualistic approach to each 'adult student', that would guarantee success. Ideas and instructions of philosophers, mentors, travelling teachers-sophists of that period stay prevalent even till these days.

\section{Pansophistic (Didaskological) period}

While analysing this period, some researchers acknowledge the andragogical approach as 'flexible' and that this idea of flexibility in the lifelong learning was practiced by the famous Czech pedagogue -humanist, the founder of the scientific pedagogy Y. Komeskyy (1592 - 1670).

Also, the views of the Yan Amos Komeskyy were important with regards to the training of the prospective PE teachers. In his famous work 'Pansophia', the pedagogue says 'we need to build a new school unlike the existent middle-aged one, that would teach the skills and knowledge, necessary for the ever-changing life' [18, p. 38]. According to his believes, 'new ideals demand the youth would be taught and be learning in a way that nothing would make they feel lost and unprepared' [18, p. 38]. Y. A. Komenskyy thinks that this education can only be provided by the pansophia, the science about everything, that is bases on common grounds, is pursuing the universal truth and harmony. We share this idea with the famous pedagogue-humanist, because a human is '.. a product of the social environment that needs a constant development and that an educational process follows 


\section{Denysenko Nataliia}

them all the time' $[18$, p. 38]. The researcher was convinced that the teacher, the creator of the future needs to know a lot; to possess the talent of teaching; to know why and when to express firmness; to know how to encourage children to explore and learn; to quickly change the educational system (if needed) etc. Also, Y. A. Komenskyy provided the justification for the complex science about a teacher - 'didaskology', the aim of which was the improvement of professional training of a teacher and their competency.

For the purposes of analysis of this period, our attention was diverted to other works of Yan Amos Kamenslyy as well. While examining his works 'The Great Deduction' (1628), which became known as one of the most important works on 'flexible pedagogy', we saw that Y.A. Komeskyy reached the conclusion about the necessity of a lifelong learning and justified this idea. We agree with the ideas of various scientists, T.O. Laserevych for instance, that the conceptual legacy of Y.A. Komenskyy gives the reasons to consider him as the founder of the flexible pedagogy and andragogy, even though the famous pedagogue was never actually using those terms himself [9, p. 15].

Thus, the analysis of the pan-sophistic period of the lifelong learning helped to find the ways of formation of a professional mobility of prospective PE teachers, as well as new requirements for the said specialists, including those regarding their adaptation to new professional circumstances.

\section{The Reformation period of K. D. Ushinskyy}

Considering the understanding of history in the context of our research, the second half XIX c. - beginning of XX c., known as the "period of the reformation' in adult education, hold a particular interest to us. As O. V. Sychomlynska claims '.. this century gave us a large number or great figures of scientist and teachers, that have demonstrated a wide variety of views on education and teaching' $[16$, p. 6]. A good example of growing attention to this period is the work of a famous teacher K. D. Ushinskyy (1824-1870), who dedicated significant attention to the questions of adult education.

The research of S. S. Marchuk 'The ideas of physical education of school children in a teaching legacy of K. D. Ushinskyy' (Lutsk, 2015) illustrates the scientific interest to the pedagogical legacy of K. D. Ushinkyy. This caused the emergence of new research into the life of the pedagogue, re-reading of his works in order to solve modern educational problems and find new rational flexible ways of overcoming the difficulties of 


\section{Andragogic approach as a basis for the formation of professional mobility...}

the modern teaching activities. The researcher also notes that the formation of the flexible personality in a modern PE practice 'calls for the teachers, scientists, educators, practitioners to start creatively using the legacy pf the progressive teachers of the past. That includes the famous Ukrainian pedagogue and democrat, a professor, a school education activist, a writer, a leading figure in the national and international pedagogical and psychological science - Konstantin Dmytrovych Ushinskyy. His scientific legacy and enlightening activities hold one of the key positions in the history of the Ukrainian teaching thought' $[11$, p. 3].

K. D. Ushinskyy forms the idea of the flexible compensatory approach in the adult education for the first time: '.. better if the student leaves the school without having the theoretical knowledge than having the theoretical knowledge alone and nothing besides that' [17, p. 28]. The scientist expresses the idea of the non-stop education, giving the priority to the tasks of the weekend schools - to develop 'an aspiration and ability for the independent learning, acquisition of new knowledge and lifelong learning, without the assistance of a teacher' in adult students [17, p. 22]. He suggested the methods of adult education, showed the necessity of the differentiation and individualisation (the separation of weekend schools into those for females and males) [17, p. 22].

The valuable observations regarding our research by S. L. Soloveichyk helped to establish that in $60 \mathrm{~s}$ of the XIX c. the youth was presented with the opportunity to express personal flexibility and work in different directions. Thus, in the book 'The age of learning. The lives of the great teachers' it is stated that '.. at this time precisely the capitalist entrepreneurship was actively developing, all the social classes needed 'individuals -activists'. At his time the initiative was valued, as well as the lively character, bright and precise word. The researcher thinks that K. D. Ushinskyy with his articles showed this general necessity in flexibility, meaning the ability to raise individuals capable of adapting to the ever-changing conditions in life [15, p. 22].

Thus, by making the comparative analysis of the ideas of the local teacher- democrat K. D. Ushinskyy, we reached the conclusion that the ideas of flexibility emerged in the national education at the end of the XIX century, when the capitalist entrepreneurship was actively developing and there was a need for action in different forms. For instance, K. D. Ushinskyy thought that the adult education was facing the need to raise the flexible 


\section{Denysenko Nataliia}

individuals, the individuals of an action. The analysis of the Reformation period confirms the belief that the professionals characterised as 'a person of an action' in the labour market tend to be: competitive; with a greatly increased 'value'; full of employment opportunities. They are also more successful in fulfilling their professional duties, especially in the non-standard situations; their chances for a dignified employment in the modern globalised world increase.

\section{Explicit period (second half of XVIII c. - XIX c., begging of XX c.).}

In this period the social circumstances, ideas of the famous philosophers, distinguished individuals and teachers, all made a valuable contribution to the development of components of teachers' professionalism. The research of M.V. Zembytska was an important stage in the development of the educational system of this historical age. After analysing the archived materials, the scientist found some negative tendencies in the flexible education of the explicit period. And this only confirmed the teachers' concern that the educational reforms of the 1980-s regarding the flexible hiring policy were dominated by the 'sink or swim' principle. This principle was characterised by ignoring the young teachers' needs and problems about the professional adaptation and growth [20, p. 181]. The scientist states that after receiving their teaching licence '...the young professionals without the due support were 'free swimming', that often looked like 'a freefall'. And this negative tendency required new educational reforms, that indeed occurred and implied the emergence of the new generation of flexible teachers' [20, p. 181].

It is worth mentioning the innovations in social development of that period modified the old traditions or started contributing something new to the social practice, something that the young generation was longing for. In this respect, we found new research in the word-wide pedagogy. For instance, the German sociology scientist and teacher Eugene Rosenstock in his speech to the Frankfurt Academy (1921) was saying that the flexibility in adult education requires new teachers, specific methods and philosophy. In his book 'Andragogy: the nature, possibilities and limits in adult education' (1951), the Swiss psychiatrist Hainrik Haselmann is using the said terminology while trying to re-educate the adults. At the same time, S. I. Zmeyov points out that in the first half of the XX century the adult aducation was not widespread and that the addragogy was not common either [21, p. 8]. 


\section{Andragogic approach as a basis for the formation of professional mobility...}

Thus, this period if defined by the 'trial and error' method in the system of flexible teacher development. At the same time, only towards the end of the XX century, the area of teaching theory and flexibility in the practice of adult education gains recognition, and the scientific understanding of adult education and the foundations of andragogy are finally formed.

\section{Mentorship period}

In this respect, we need to examine the characteristics of flexibility and readiness for the professional activity provided by the L. V. Chumak. In her work 'Genesis of the formation of the components of teachers' professional skillset: the first half of the implicit period of teaching profession formation' she discovered the division of education that was called 'mentorship'. The author characterises the explicit period as the ' ... formation of the professional skillset of the youth mentors', as ' ... the beginning of the long-lasting stage of establishing and developing the national system for teachers' support for them to conduct the professional activity'. She also describes it as '.. . the comprehension of the social value of the teaching professions and the formation of the premises for further establishing the components of the flexible teachers' skillsets, that will be valuable in the future' [2, p. 63].

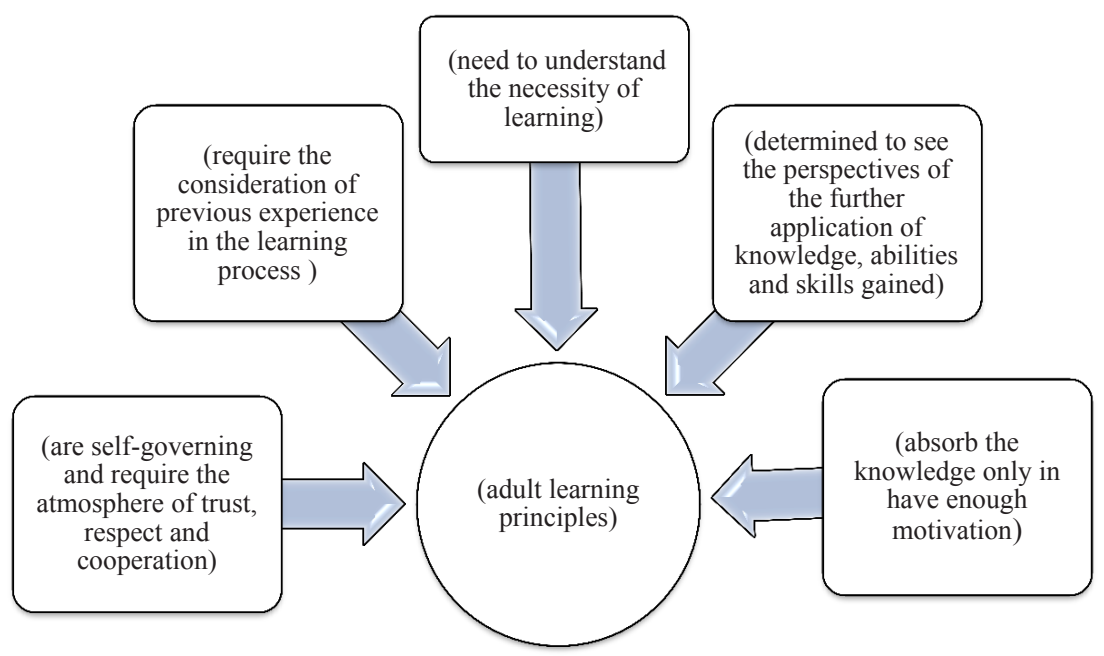

Exhibit 1. Adult learning principles (per M. Knowles) 
For example, the researchers P. A. Early. D. Weindling notice that the American teacher M. Knowles, who in 1970 used the term 'the angragogy of the mentorship' for the first time and that he claims that in adult education the determinative motivation for learning, its imperialisms, and problem-based learning are essential. M Knowles defines the six learning principles for adults, demonstrated in the Exhibit 1 [4, p. 57].

The researchers prefer 'the institutions of mentorship' that successfully operate in the USA nowadays. With similar excitement, the researchers positively assess the programmes of the 'institutions of mentorship', which are used bases on the andragogy principles and are aimed at the teaching cooperation between the mentor and the mentee. During such cooperation, the reallife educational scenarios need to be discussed, as well as modern teaching techniques be deployed, must be created the necessary environment for the independent knowledge acquisition, the formation of the personal flexibility and adaptability skills for the fast-changing real-life conditions [4, p. 57].

Thus, M. V. Zembitska thinks that the 'andragogy of mentorship' is the main engine of progress and the mentor plays the role of the coordinator, while choosing the most effective methods and forms of providing the information' [ 20, p. 182]. The most interesting from the perspective of the physical education (and we agree with that) are the researcher's views on the appropriateness of using the mentorship as the process for the flexibility formation among the prospective PE teachers.

Hence, the modern take on the mentorship period has demonstrated that the reforms of the 1980-s gave a start to the modernisation of the flexibility system and to the psychological and professional support for the teachers, their professional growth and development. During the next three decades, there has been numerous research done, that proved the direct connection between the mentors' influence and the psychological well-being of the future teachers, the quality of training in the HEE and the formation of their professional flexibility.

\section{Constructively -flexible period in adult education}

The collective monography edited by L. M. Kapchenko 'Andragogical foundations of professional education for unemployed' (2013), describes those times views on education. The researchers point out that the promotion of the constructive pedagogy in different forms at the end of XX beginning of XXI centuries can be seen in different countries of the world. In Yugo- 


\section{Andragogic approach as a basis for the formation of professional mobility...}

slavia in 1969 the journal on the adult education called 'Andragogy' was founded, there was a 'Flexible Yugoslavian Union of Andragogy', and in 1993 Slavic 'Andragogic Centre of the Republic of Slovenia' and the journal 'The Knowledge of Andragogy' started operating. The International Institute of Andragogy was opened in Venezuela. The Korean 'Organisation of Adult Education and Lifelong Learning' publishes a journal 'The Andragogy today', China is actively pursuing andragogic research as well...' [7, p. 9].

We can observe that the problem of flexibility in adult education is the burning issues for the scientists from the different countries. The most in-depth research was made by E. Lindenmann, M. Knowles (USA), Turos (Poland), S. Zmeev (Russia), N. Hychkalo, L. Lukyanova, L. Sigaeva (Ukraine) and others. The scientific literature analysis conducted by the Doctor of the Pedagogical Sciences, Professor T. M. Desyatov, shows that 'the official recognition of the constructive andragogy' in the European countries and the USA was happening during the 70s of the XX century. This is linked to the publication of the research 'Contemporary Adult Education. Andragogy versus Pedagogy' by the American scientist Malcolm Knowles, in which the conceptual foundations of a new science are justified.

Hence, while researching this period, we were mostly interested in the increase in numbers of the professional higher education providers, who incorporate the special science - andragogy into their programmes for modernisation of training for the future teachers. In particular, the andragogy becomes constructively-flexible, as evidenced by the experience of Yugoslavia, Slovenia, Venezuela, Poland, China, the United States of America, Ukraine, Russia, Germany. But, unfortunately, the scientists of this historical period have not formed the specific uniform definition of andragogy in terms of formation of professional flexibility on the prospective PE teachers. This area has its own peculiarities and this is conceptually significant for the purposes of our research. It is also worth mentioning that in this historical period there has been profound examination of materials regarding the competency-based approach. It would be logical to explore the content of this period.

\section{The competency (teamwork) period}

It should be noted that the competency period has become the turning point in research regarding the formation of the professional flexibility of the prospective PE teacher, their competitiveness, ability to tackle new rec- 
reational and educational tasks. This period is actively referred to during the last 10-15 years as 'competency-oriented' and 'flexible education'.

Nowadays the competency period is closely linked to the formation of the flexible study goals. As O. Ovcharuk righty notices, 'this is happening not on the national, but rather on the global, international levels, when the main educational priorities and goals are expressed in the international conventions and documents and serve as the strategical landmarks for the international community. The author thinks that this is the reason why nowadays it is important that 'an individual can not only use their own knowledge, but also is ready to change and adapt to new requirements of the labour market, utilise the information, is active, can take decisions on the spot and learn during the lifetime' $[12$, p. 6].

The views of L. Filipova deserve a special attention in terms of our research. She thinks that nowadays it is the indisputable fact that 'the professional qualities of an expert in any field are guided by the combination of knowledge, skills and abilities, gained in a certain Higher Educational Establishment. The researcher points out that the ability to deploy those characteristics 'is the primary thing that the employers look for in the modern labour market, accessing those skills against the applied, business, psychological framework and others' $[5$, p. 1]. From the point of view of employers', in particular manufacturers, businessmen and psychologists from abroad, this terms reflects on the job candidate's abilities to perform their duties according with the KSAO (Knowledge, Skills, Abilities and Other characteristics), which is important for the purposes of our research.

In particular, the scientist thinks that the competent professional (as defined by KSAO) differs from the qualified because of their flexibility, 'because the $3 / 4$ of them are utilising their professional knowledge, skills and abilities at their job; $3 / 4$ are always self-developing and push beyond the limits of their fields; $3 / 4$ consider their profession to be a precious asset'.

Let us focus on the scientific accomplishments of the foreign scientists, important for our research (Cl. Beelisle, M. Linard, B. Rey, L. Turkal, N. Guignon, M. Joras and others). They link the content of the competency period in adult education with the formation of the teamwork skills (Cl. Beelisle), with the willingness of an individual to use all their assets, necessary for accomplishing a specific task within a given situation (M. Linard, B. Rey). We should note that most of the foreign scientists describe this period as the 'teamwork' and explain that the success- 


\section{Andragogic approach as a basis for the formation of professional mobility...}

ful accomplishment of any project is not possible without a project team (L. Turkal, N. Guignon, M. Joras).

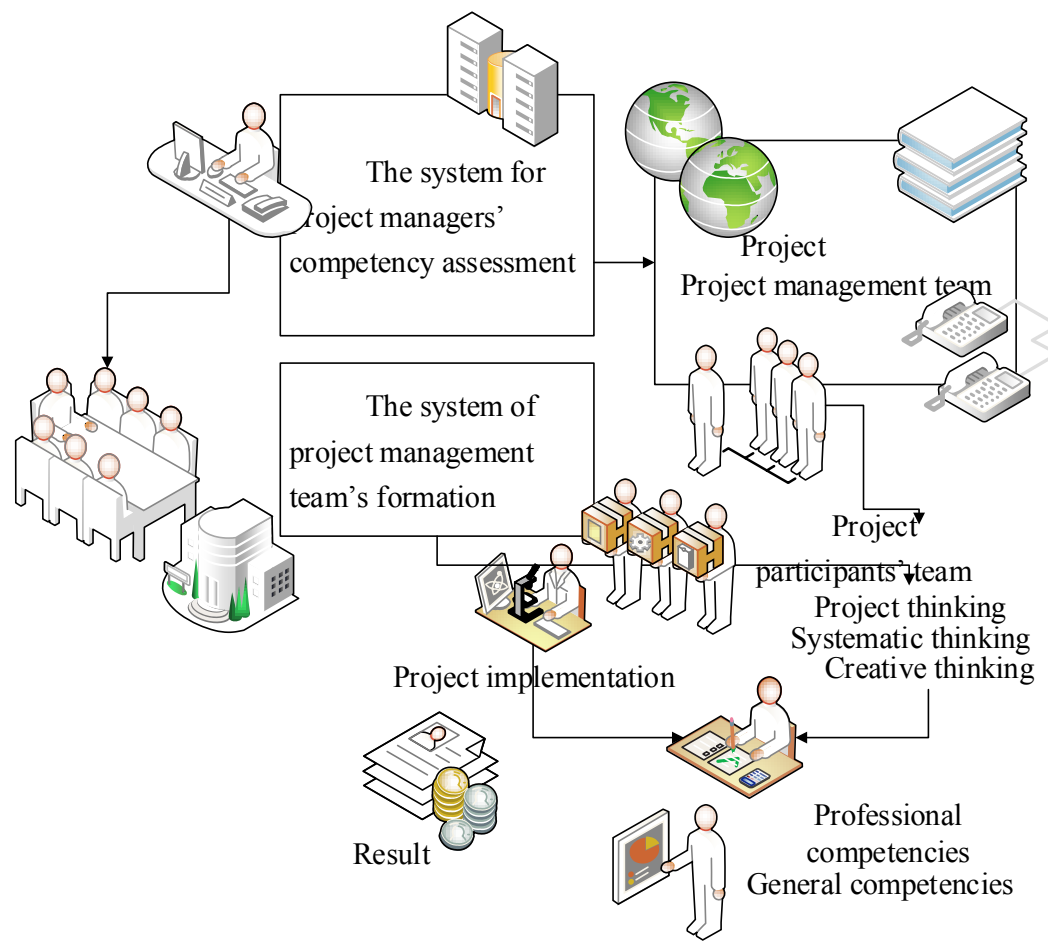

\section{Scheme 1. Generalised conceptual model of the formation} of a flexible personality, able to work in a team (as defined by KSAO)

Some national scientists suggest author's conceptual models of the team formation, separating them into 'general', 'specific' and 'instrumental' competencies, that should be used in practice. The analysis of the stated principles, based on KSAO standard, allowed us to justify the content and structure of the phenomenon examined (teamwork competency) and express it in Scheme 1. The Scheme 1 shows the generalized conceptual model of the team formation, following the specifics of the given project.

To sum up, we can claim that nowadays the high competency level of professionals is viewed as a big competitive advantage for a country. 


\section{Denysenko Nataliia}

Hence, in the international educational area we can observe a stable tendency towards the development of standards for professional education, oriented at the competency approach.

\section{Cluster period}

The analysis of the generalised conceptual model of the formation of a flexible personality, able to work in a team (as defined by KSAO), prompted us to highlight another period in the system of formation of the professional flexibility of the prospective PE teachers. The period is the cluster period, based on the 'collaboration theory'.

Cluster can mean a 'bunch', 'clump', 'collection', 'group' (for instance, of people, objects), or a 'bee hive'; as a process, it literary means 'to grow together', 'to gather in groups', 'to become overcrowded'. '». In the economic dictionary of a businessman we have a definition 'Cluster - is a group of objects that describe similar things, that possess common characteristics'. The dictionary of the foreign words defines 'cluster' - as the collection of several similar elements, that can be viewed as one item that has special characteristics.

In the pedagogical literature that describes the theory of 'collaboration', there is a lack of information regarding the connection between different establishments in terms of clusters. However, the experience of cluster politics is an effective one, while there is a growing awareness of the cluster philosophy in the international community and the clusters themselves are becoming the key components of the nationals and regional economic development plans.

The examination of the cluster processes, global experience of cluster formation and the characteristics of cluster politics in different countries was made in different works of local and foreign scientists, for instance: M. E. Porter, M. P. Voynarenko, S. I. Sokolenko, N. A. Mikula, P. Y. Belenkiy, O. M. Tyschenko, I. V. Brykova, O. V. Annenkova, V. I. Chuschykov and many others. The results of the scientific works' analysis show that in many developed countries (USA, Canada, Japan, Finland, France, Germany, Italy and others) clusters became an effective instrument for increasing the competitiveness of the territories. At the same time in each country, clusters have their own characteristics, specifics of organisation and functioning.

Swedish educational cluster, based in the Uppsala University and the

'Research Triangle' cluster in the North Carolina (USA) are the successful 


\section{Andragogic approach as a basis for the formation of professional mobility...}

examples of these structures functioning abroad'. We should note that in our country we also have some positive cluster experience. Chmelnytska region should be considered as the pioneer of 'clusterisation' in Ukraine, where before the 2000 there were several industrial clusters formed - those formanufacture, construction, nutrition, tourism and green rural tourism.

We also appreciate the scientific position of E. R. Chernyshova stating that '...the result of educational cluster activity is the diffusion of the innovative activity from one subject of productive relationship to another. That is why the clusters can be the basis for formation of effective flexible-national system for the preparation of prospective PE teachers' [1, p. 189].

Unfortunately, nowadays in Ukraine, as evidenced by E. R. Chernyshova 'there is no legal basis for the cluster politics implementation, there is no law supporting this model of the country development' [1, p. 189].And still, in the framework of our research, we can observe a number of Ukraine's positive starting steps regarding the cluster politics in education. Having the aim of organising the research into the issues of scientific- educational cluster formation, the scientific centre 'University of Educational Management' of NAPS established the "Virtual Laboratory 'Scientific educating cluster UMO" on 15 January 2015. Such projects use the national and international developments in different areas and check whether they are appropriate for the research of selected areas of science. Such projects use the national and international developments in different areas and check whether they are appropriate for the research of selected areas of science. Unfortunately, so far this does not apply to the area of the Physical Education.

Thus, based on the current research, we will try to develop and experimentally prove our own conception of the educational cluster formation of the professional flexibility of the prospective PE teachers. The research will be based on the Higher Pedagogical Educational Establishment (HPEE) 'the Academy of Recreational Technologies and Law' (Lutsk, Volyn region), 'Lutsk Pedagogical College' and their functioning model. In our opinion this is a very important and current idea, that needs to be implemented in practice. We are convinced that cluster union will enable their participants gain certain advantages through:

1) firstly, mastering the new information search methods, information and knowledge exchange, receiving new flexible-professional academic opportunities; 


\section{Denysenko Nataliia}

2) secondly, increasing the number of the innovation-oriented partners, reducing the risks occurring during the organisation of joint recreational projects;

3 ) thirdly, increasing the adaptability level to the external fast changing environment;

4) fourth, it will encourage to overcome the barriers between the regional educational establishments, difficulties in communication among the experts and students from different scientific fields;

5) fifth, with the changes in mechanisms of governmental funding of the educational system, planned by the new laws, our Volyn educational establishments will have to compete not just among themselves, but also with the other regions of Ukraine, in order to attract better students;

6) sixth - the opportunities to access scarce resources and competencies;

7) seventh, it is becoming more common that we have to compete against the Polish and European Universities, that are opening their doors for the best Ukrainian students. The only way to remain competitive - 'is to improve the quality and form the culture of quality'. This is best done collectively, in a functioning academic environment.

Thus, the study of the andragogical approach history has discovered a considerable amount of the academic literature, that encompasses the issues and problems, similar to those of the history of adult education. Those issues are about the establishment of the progressive tendencies in training of the flexible teaching workforce. The analysis of the academic literature's content verifies the existence of the phenomenon, such as 'adult education', 'flexible education', 'competency', 'creativity', 'resourcefulness', 'mentorship', 'tutoring', 'enterprise', 'persistence', 'perseverance' and the constant interest towards those, as the resource for the flexible individual formation, by the theorists and practitioners.

\section{Conclusions}

Based on the research of scientists from different historical periods regarding the andragogic approach in the system of formation of the flexible PE teacher, we have found interesting overlaps and parallels. Those enabled us to comprehend the decisive role of educating the adult person, who is capable of expressing the personal flexibility throughout the lifetime. As the result of the historical-pedagogical analysis we tried to examine the periodisation of the flexibility genesis in adult education, as well as justified the general tendencies and established the characteristics of its development in different historical eras 


\section{Andragogic approach as a basis for the formation of professional mobility...}

The result of this analysis is that we have distinguished several relevant periods: the Sophistic period (Ancient history), Middle Ages; the Pan-sophistic period (New Age XVII century); the period or Reformation by K.D. Uschynskyy (second half XIX c. - beginning of XX c.); the Explicit period (second half of XVIII c. - XIX c.); the Constructively -flexible period in adult education (end of XX c. - begging of XXI c.); the Mentorship period (70-s to present); the period of Competency (in active use in 60-s of XX c. and is still used nowadays); the Cluster period (starting from 2000 in Ukraine and until nowadays). Also, the analysis of the academic literature enabled us to reach a conclusion that the most valuable specialist for any society (of different historical periods) is the one that has got the ability to self- improve throughout the lifetime and the desire to form the personal professional flexibility. We have to highlight the fact that in the European countries, in addition to the term lifelong education, the terms that signify the different aspects of continuity in education are very common: for instance, continuing education, recurrent education, permanent education, further education, postgraduate education, adult education, remedial education etc. The researcher of the modern education reforms highlight that the same phenomena can be expressed in the different terms, views and definition. However, we also note that the analysis of the andragogic approach regarding the system of formation of professional flexibility of the prospective PE teachers enables us to state that there has been no complete systematic research done. We only have separate isolated examples dealing with the development of signature flexibility projects in physical education.

The absence of the systematical educational studios concerning the stated problem is also manifesting into the discrepancies between the objective need in flexibility formation in prospective PE teachers and the insufficient level of inquiry into this matter, generalisation in the historical-pedagogical literature. Also, there is an inconsistency between the awareness of the role and importance of the 'flexible personality', its main principles and the capacity to implement that into the teaching practice of the modern educational establishments.

Hence, the necessity to eliminate the above-mentioned inconsistencies requires an awareness and the theoretical and methodological justification of the modern provisions regarding the system of professional flexibility formation among the prospective PE teachers in the Higher Educational Establishments. 


\section{Denysenko Nataliia}

\section{References:}

1. Chernyshova Ye.R. (2012). Metodyka otsinky mizhnarodnoi konkurentospromozhnosti pidpryiemstv [Methodology of rating the international competitiveness of factories]. [Electronic resource]. Economic strategy and perspectives for the trade and service development, vol. 2, pp. 189-197. Retrieved from: http://nbuv.gov.ua/UJRN/esprstp_2012_2_29. [in Ukrainian].

2. Chumak L.V. (2014). Intehratyvnyi fenomen profesiinoi maisternosti vchytelia [ The integrative phenomenon of professional teacher's art]. Pedagogical education: theory and practice. Pedagogy, no. 21, pp. 63-68. Retrieved from: http://nbuv.gov.ua/UJRN/Potip_2014_21_14. [in Ukrainian].

3. Demchenko N. (2013). Neperervna profesiina osvita fakhivtsiv aviatsiinoi haluzi [Uninterrupted professional education of specialists in the aviation industry]. [Electronic resource]. The theory and methodology of education management, vol. 10. Retrieved from: http://nbuv.gov.ua/UJRN/OD_2013_6_5. [in Ukrainian].

4. Early P. (2004). A changing discourse : from management to leadership. Understanding school leadership. London : Paul Chapman Publishing, 175 p. [in English].

5. Filipova L. (2009). Profesiini kompetentsii fakhivtsiv z dokumentalnykh komunikatsii: osvitnii aspect. [Professional competences of documental communication specialists: educational aspect]. [Electronic resource]. The bulletin of Book Chamber, vol. 1, pp. 25-28. Retrieved from: http://nbuv.gov.ua/UJRN/ vkp_2009_1_15. [in Ukrainian].

6. Herasymova I. (2013). Kontseptsiia formuvannia profesiinoi mobilnosti maibutnikh fakhivtsiv ahrarnoi sfery [Conception of professional mobility formation of future specialists in the agrarian sector]. [Electronic resource]. Education for adults: theory, experience, perspectives, vol. 5, pp. 35-45. Retrieved from: http://nbuv.gov.ua/UJRN/OD_2013_6_5. [in Ukrainian].

7. Kapchenka L.M. (2013). Añdrahohichni zasady profesiinoho navchannia bezrobitnykh : Kolektyvna A 66 monohrafiia [Andragogical foundations of professional education for unemployed: collective monograph]. K.: IPK DSZU, 124 p. ISBN 978-617-649-022-7. [in Ukrainian].

8. Kovalchuk V. A. (2016). Profesiina pidhotovka maibutnikh uchyteliv do roboty $v$ umovakh variatyvnosti osvitno-vykhovnykh system [Professional training of future teachers for work in conditions of educational systems variability]. The bulletin of the Glukhiv National Pedagogical University named after Alexander Dovzhenko. Series: Pedagogical Sciences, vol. 30, pp. 13 - 22. [in Ukrainian].

9. Lazarevich A. A. (2014). Innovatsionnoye razvitiye i problemy legitimizatsii nauki [Innovative development of science and problems of its legitimization]. [Electronic resource]. Scientific works of [The Black Sea National University named after Petro Mohyla of the complex "Kyiv-Mohyla Academy"]. Series: Sociology. T. 234, vol. 222, pp. 14-18. Retrieved from: http://nbuv.gov.ua/UJRN/ Npchdusoc_2014_234_222_4. [in Russian].

10. Levchenko Yu. (2010). Postat nastavnyka u vykhovnii tradytsii antychnosti [Image of mentor in the educational tradition of antiquity]. [Electronic resource] Youth and Market, no. 1-2, pp. 130-134. Retrieved from: http://nbuv.gov.ua/UJRN/ Mir_2010_1-2_31. [in Ukrainian]. 


\section{Andragogic approach as a basis for the formation of professional mobility...}

11. Marchuk S.S. (2015). Idei fizychnoho vykhovannia shkoliariv u pedahohichnii spadshchyni K. D. Ushynskoho: dys. ... kand. ped. nauk: 13.00 .01 [Ideas of physical education for pupils in the pedagogical heritage of K. D. Ushinsky: dissertation of Candidate of Pedagogical Sciences: 13.00.01]. Lutsk, 264 p. [in Ukrainian].

12. Ovcharuk O.V. (2004). Kompetentnisnyi pidkhid u suchasnii osviti: svitovyi dosvid ta ukrainski perspektyvy. [Competence approach in the modern education: world experience and Ukrainian perspectives]. Library of educational policy. K. : KIS, 112 p. [in Ukrainian].

13. Piletska L. S. (2013). Profesiina mobilnist osobystosti: psykholohichnyi aspekt analizu [Professional mobility of person: the psychological aspect of the analysis]. [Electronic resource]. Theoretical and applied problems of psychology, no. 3, pp. 205-210. Retrieved from: http://nbuv.gov.ua/UJRN/Tippp_2013_3_35. [in Ukrainian].

14. Savchenko O. P. (2010). Kompetentnisnyi pidkhid u suchasnii vyshchii shkoli [Competence approach in the modern higher school]. Pedagogy and Science: history, theory, practice, tendencies of development, vol. 3, pp. 16-23.

15. Soloveychik S. L. (1972). Chas uchenichestva. Zhizn zamechatelnykh uchiteley [The time of learning. The life of wonderful teachers]. Vol. 2, M. : Children Literature. [in Russian].

16. Sukhomlynska O. V. (2013). K. D. Ushynskyi na tli doby [Ushinsky on the background of the age]. [Electronic resource]. The bulletin of the Chernihiv National Pedagogical University. Pedagogical Sciences, vol. 110, pp. 6-8. Retrieved from: http://nbuv.gov.ua/UJRN/VchdpuP_2013 110_4. [in Ukrainian].

17. Ushynskyi K. D. (1983). Vybrañi ped̄ahohichni tvory : v 2-kh t. T. 1. [Selected pedagogical works: in 2 t. T. 1.]. Theoretical problems of pedagogy. K. : Soviet school, 488 p. [in Ukrainian].

18. Vykhrushch V. (2013). Pansofiia Ya. A. Komenskoho yak osnova zabezpechennia komparatyvistskoho pidkhodu v istorii dydaktyky [Ya. A. Komenskyi`s Pansofia as a basis for providing the comparative approach in the history of didactics]. [Electronic resource]. Problems of modern teacher's training, no. 8 (2), pp. 38-45. Retrieved from: http://nbuv.gov.ua/UJRN/ppsv_2013_8(2)_8. [in Ukrainian].

19. Yudin E. G. (1978). Sistemnyy pokhod i printsip deyatelnosti: metodologicheskiye problemy sovremennoy nauki [Systemic approach and the principle of activity: methodological problems of the modern science]. M. : Science, 391 p. [in Russian].

20. Zembytska M. V. (2015). Kontseptualni pidkhody do zdiisnennia nastavnytstva molodykh uchyteliv u SShA [Conceptual approaches for mentoring of young teachers in the United States]. The bulletin of the Zhytomyr National University named after Ivan Franko, vol. 1, pp. 179-185. Retrieved from: http://nbuv.gov.ua/ UJRN/VZhDU_2015_1_37. [in Ukrainian].

21. Zmeyev S. I. (2007). Andragogika: osnovy teorii. istorii i tekhnologii obucheniya vzroslykh [Andragogy: the fundamentals of theory, history and technology of adult learning]. M.: PER SE, 272 p. [in Russian]. 